\title{
Diversity of Wild Bees along Elevational Gradient in an Agricultural Area in Central Java, Indonesia
}

\author{
Imam Widhiono, Eming Sudiana, and Darsono Darsono \\ Faculty of Biology, Jenderal Soedirman University, Jl. Dr. Soeparno no. 63 Purwokerto, Central Java 53122, Indonesia \\ Correspondence should be addressed to Imam Widhiono; imamwidhiono@yahoo.com
}

Received 6 December 2016; Accepted 12 January 2017; Published 31 January 2017

Academic Editor: Jacques Hubert Charles Delabie

Copyright ( 2017 Imam Widhiono et al. This is an open access article distributed under the Creative Commons Attribution License, which permits unrestricted use, distribution, and reproduction in any medium, provided the original work is properly cited.

\begin{abstract}
Increases in mean temperature affect the diversity and abundance of wild bees in agricultural ecosystems. Pollinator community composition is expected to change along an elevational gradient due to differences in the daily ambient temperature. This study investigated the diversity and abundance of wild bees in an agricultural area along an elevational gradient in Central Java, Indonesia. Wild bees were collected using a sweep net in 40 green bean (Phaseolus vulgaris) cultivation sampling locations at seven different elevations $(8,108,224,424,644,893$, and $1017 \mathrm{~m}$ above sea level). Species diversity was determined using the Shannon-Wiener diversity index. We identified 932 individuals from 8 species of wild bee belonging to 3 families. The family Apidae was predominant, with 6 species, while only 1 species was found from each of Megachilidae and Halictidae. Across the study sites, diversity increased with increasing elevation $\left(\left(H^{\prime}\right)=1.4,(D)=0.25\right.$, and $(E)=0.78$ at low elevation to $\left(H^{\prime}\right)=2.04, D=0.13$, and $E=0.96$ at high elevation), and higher numbers of species were found at middle and high elevations. Species richness and abundance increased linearly with increasing elevation, and species diversity was highest at middle elevations.
\end{abstract}

\section{Introduction}

Wild bees (order Hymenoptera: Apoidea) represent the most important group of pollinator insects because they play a key role in agriculture, pollinating almost all crop varieties. However, they are increasingly at risk of local and even global extinction due to climate change [1], which can disrupt the overlap of flower production and pollinator flight activity [2]. The major characteristic of climate change is an increase in the mean global temperature. Elevated temperatures are known to influence the foraging activity, body size at maturity, and individual lifespan [3] of wild bees. The physiological impacts of climate warming might not have negative effects on individual insect pollinators; in fact, some could even have positive effects. Increases in mean temperature affect the diversity and abundance of wild bees in agricultural ecosystems.

Elevational gradients can be used as model systems for climatic change to analyse the role of environmental filtering effects on animal communities [4]. Comparative studies of species ecology along elevational gradients can provide clues to the likely response of both species and communities in the study of the effects of increasing temperature on the diversity and abundance of pollinator insects. However, there are significant differences among the characteristics of typical elevational gradients. Pollinator community composition is expected to change along an elevational gradient due to differences in ambient daily temperature. Due to the harsher environmental conditions, the number of pollinator species tends to decrease with increasing elevation [5]. The relative abundance of Hymenoptera has been negatively correlated with increasing elevation [6]. However, some studies have found that Hymenoptera, especially wild bees, are the most abundant floral visitor at high elevations, at least for some plant species [7]. Total pollinator richness [8] and abundance [9] have been found to decrease with increasing elevation, with plants becoming more ecologically specialised at higher elevations [10]. However, to the best of our knowledge, the wild bee diversity and abundance along an elevational gradient in agricultural areas has not previously been studied 


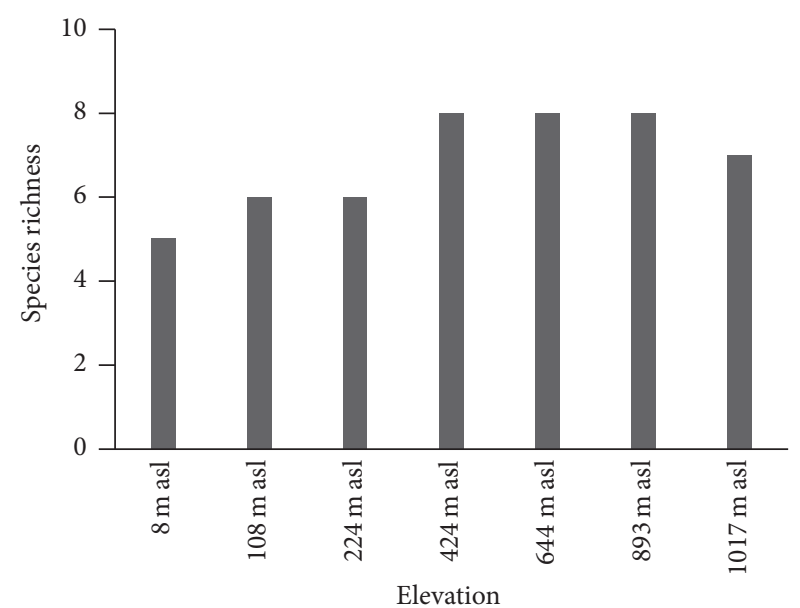

(a)

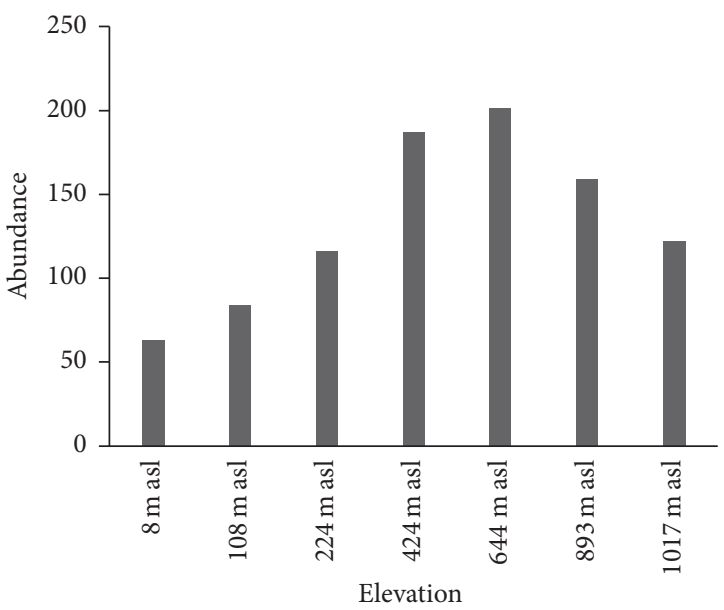

(b)

Figure 1: Species richness (a) and abundance (b) of wild bees among elevation.

in Java. In this study, we investigated the diversity and abundance of wild bees in an agricultural area along an elevational gradient to test the hypothesis that elevation is a significant factor underlying the species composition and abundance of wild bees.

\section{Materials and Methods}

2.1. Study Area. The study was conducted in areas of green bean (Phaseolus vulgaris) cultivation at seven locations along an elevational gradient: Lomanis, Cilacap Regency $\left(7^{\circ} 41^{\prime} 06\right.$ $32^{\prime \prime} \mathrm{N}, 109^{\circ} 01^{\prime} 1224^{\prime \prime} \mathrm{E}, 8 \mathrm{~m}$ above sea level (asl)), Gunung Tugel, Purwokerto $\left(7^{\circ} 28^{\prime} 0392^{\prime \prime} \mathrm{N}, 109^{\circ} 14^{\prime} 0635^{\prime \prime} \mathrm{E}, 106 \mathrm{~m}\right.$ asl), Banteran, Sikapat, and Banyumas Regency $\left(7^{\circ} 20^{\prime} 0043^{\prime \prime} \mathrm{N}\right.$, $109^{\circ} 16^{\prime} 2949^{\prime \prime} \mathrm{N}, 224$, and $442 \mathrm{~m}$ asl, resp.), Limpakuwus and Tuwel, Tegal Regency $\left(7^{\circ} 09^{\prime} 4638^{\prime \prime} \mathrm{N}, 109^{\circ} 09^{\prime} 0666^{\prime \prime} \mathrm{E}, 664\right.$ and $887 \mathrm{~m}$ asl), and Serang, Pubalingga Regency $\left(7^{\circ} 14^{\prime} 48\right.$ $41^{\prime \prime} \mathrm{E}, 109^{\circ} 17^{\prime} 2891^{\prime \prime} \mathrm{N}, 1077 \mathrm{~m}$ asl). In the regions, green bean is a minor vegetable crop that extensive planting is usually very small and located on land planted with other types of vegetables such as long bean, but, as for research purposes, this plant was chosen because it was found at all altitudes.

2.2. Sampling of Bee Diversity and Identification. The seven long bean plantations were sampled twice each month from April to June, 2014. We collected 100 plant individuals at each site, using the standard sweep net procedures described by Brosi et al. [11] (2008) to sample the bees. During each sampling session, 14 members of the field team (two persons per location) aerially netted bees over 30 min periods. Bees both on flowers and in flight were collected individually with the sweep net. Sampling was performed in the morning (07:00-09:00 local time) on fine days. Bee species were identified by the Indonesian Institute of Science, Bogor. Voucher specimens are held at the Entomology Laboratory, Faculty of Biology, Jenderal Soedirman University, Indonesia.
2.3. Statistical Analyses. The species richness and abundance of wild bees recorded in the seven plots were analysed. A general linear model was applied using SPSS ver. 18.0 software. The dependent variables were wild bee species richness and abundance, and the categorical variables were elevation and daily temperature. Raw data from the field were used to reveal species richness, species diversity (ShannonWeiner index), component of dominance (Simpson dominance index), and relative abundance of different species at each sampling site [12]. Comparisons of species composition according to location were performed using single linkage cluster analysis based on Bray-Curtis similarity. All diversity parameters were analysed using Biodiversity Pro software [13].

\section{Results and Discussion}

3.1. Species Composition. In total, 932 individual wild bees belonging to 8 species, 5 genera, and 3 families were collected during the study period. Apidae was the most dominant family, with 6 species (Xylocopa latipes, X. confusa, X. caerulea, Apis cerana, A. dorsata, and Amegilla cingulata), and two families (Megachilidae and Halictidae) were represented by one species each. The composition of wild bee species found at the seven elevations varied, with the largest number of species (8) at the middle-to-high elevations (442-1017 m asl), and the lowest species richness at the lowest elevation ( $8 \mathrm{~m}$ asl), with only 3 species. Xylocopa latipes, X. confusa, Apis cerana, and Megachile relative were observed at most elevations. Apis dorsata and Xylocopa caerulea were found only at the middle and high elevations (Figure 1(a)). Species richness differed significantly among elevations (analysis of variance (ANOVA): $F_{6,49}=5.445, p=0.000223<0.05$ ). Increasing elevation increased wild bee species richness up to $893 \mathrm{~m}$ asl $\left(R^{2}\right.$ $=0,84)$ and then decreased species richness above $1017 \mathrm{~m}$ asl (Table 1). 
TABLE 1: Species composition, abundance, and diversity of wild bees and seven different elevations.

\begin{tabular}{|c|c|c|c|c|c|c|c|c|c|}
\hline \multirow{2}{*}{ Species } & \multicolumn{7}{|c|}{ Elevation $\mathrm{m}$ above sea level (asl) } & \multirow{2}{*}{ Abundance } & \multirow{2}{*}{ Relative (\%) } \\
\hline & 8 & 108 & 224 & 424 & 644 & 893 & 1017 & & \\
\hline Xylocopa latipes & 18 & 26 & 25 & 27 & 26 & 22 & 16 & 160 & 17,16 \\
\hline Xylocopa confusa & 15 & 14 & 19 & 44 & 26 & 19 & 23 & 160 & 17,16 \\
\hline Xylocopa caerulea & 0 & 0 & 0 & 15 & 29 & 31 & 22 & 97 & 10,4 \\
\hline Apis cerana & 20 & 23 & 37 & 44 & 38 & 27 & 0 & 189 & 20,2 \\
\hline Apis dorsata & 0 & 0 & 0 & 21 & 26 & 16 & 11 & 74 & 7,9 \\
\hline Amegilla cingulata & 1 & 4 & 11 & 8 & 22 & 13 & 17 & 76 & 8,1 \\
\hline Megachile relativa & 9 & 10 & 11 & 16 & 20 & 18 & 19 & 103 & 11,05 \\
\hline Lasioglossum malachurum & 0 & 7 & 13 & 12 & 14 & 13 & 14 & 73 & 7,8 \\
\hline Abundance & 63 & 84 & 116 & 187 & 201 & 159 & 122 & 932 & \\
\hline Relative (\%) & 6,7 & 9,01 & 12,44 & 20,06 & 21,56 & 17,06 & 13,09 & & \\
\hline Mean temperature ${ }^{\circ} \mathrm{C}$ & 34,3 & 32,5 & 31,2 & 30,4 & 29,8 & 29 & 28,7 & & \\
\hline Shannon_H & 1,408 & 1,622 & 1,684 & 1,93 & 2,045 & 2,035 & 1,919 & & \\
\hline Simpson_1-D & 0,740 & 0,778 & 0,7944 & 0,8361 & 0,8665 & 0,8634 & 0,8498 & & \\
\hline Evenness_e $e^{\wedge} \mathrm{H} / \mathrm{S}$ & 0,817 & 0,843 & 0,897 & 0,860 & 0,966 & 0,956 & 0,973 & & \\
\hline
\end{tabular}

3.2. Abundance. In total, 932 individual wild bees belonging to 8 species, 5 genera, and 3 families were recorded. Site 1 supported 4 species with 63 individuals $(5.8 \%$ of all individuals); Site 2, 5 species and 84 individuals (9.01\%); Site 3, 5 species and 116 individuals (12.44\%); Site 4, 7 species and 187 individuals (20.06\%); Site 5, 8 species and 201 individuals (21.5\%); Site 6, 8 species and 169 individuals (17.06\%); and Site 7, 7 species and 122 individuals (13.09\%) (Figure 1(b)).

Wild bee abundance differed significantly among sites (ANOVA: $F_{6.49}=3.478, p=0.006<0.05$ ). The most abundant species was Apis cerana with 189 individuals (20.2\%), followed by $X$. confusa and $X$. latipes, each with 160 individuals (17.16\%), M. relativa with 103 individuals (11.05\%), X. caerulea with 97 individuals (10.4\%), A. cingulata with 76 individuals (8.1\%), and $A$. dorsata with 74 individuals (7.9\%), and the least abundant was L. malachurum with 73 individuals (7.8\%). Comparing the wild bee abundance among sampling events at all elevations, the highest abundance was from sampling number 2 with 199 individuals (21.3\%), followed by sampling number 1 with 172 individuals (18.4\%), sampling number 4 with 157 individuals (16.8\%), sampling number 3 with 148 individuals (15.8\%), sampling number 5 with 136 individuals $(14.5 \%)$, and the lowest abundance was from sampling number 6 with 120 individuals (12.8\%). However, statistical analysis revealed no significant differences among sampling events (ANOVA: $F_{5.42}=1.01800 p=0.419>0.05$ ).

Across the study sites, diversity increased with increasing elevation (Shannon-Wiener index $\left(H^{\prime}\right)=1.4$, dominance $(D)$ $=0.25$, and evenness $(E)=0.78$ at low elevation to $\left(H^{\prime}\right)=$ 2.04, $D=0.13$, and $E=0.96$ at high elevation), and higher numbers of species were found at middle and high elevations. The distribution of wild bees among the sites was significantly influenced by elevation. The richness, abundance, diversity, and evenness of wild bees at different sites are presented in Table 1.

Analysis of community structure similarity among elevations showed that the three sites categorised as low elevation (8-224 $\mathrm{m}$ asl) had high similarity (84.53\%), the two middleelevation sites (424-644 $\mathrm{m}$ asl) had $83.50 \%$ similarity, and

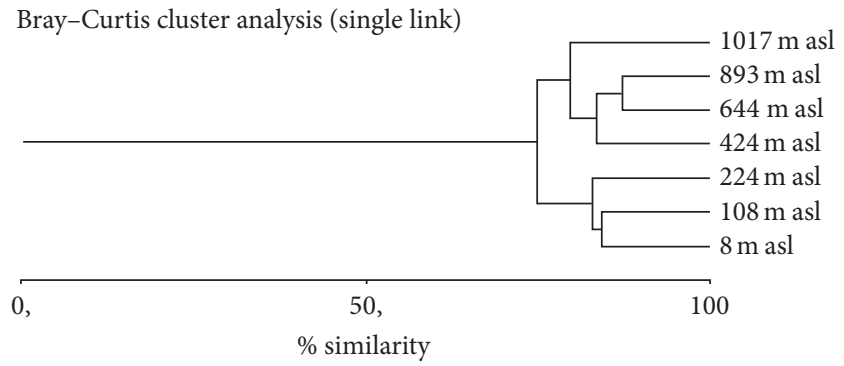

Figure 2: Similarity (Bray-Curtis) single linkage of wild bee in seven different elevations.

the two high-elevation sites ( $893 \mathrm{~m}-1017 \mathrm{~m}$ asl) had $79.7 \%$ similarity. However, the highest species similarity $(87.2 \%)$ was found between Site 5 (644 $\mathrm{m}$ asl) and site 6 (893 $\mathrm{m}$ asl) (Figure 2).

\section{Discussion}

The number of wild bee species and the species composition recorded in this study were similar to those reported in previous studies in various regions. Hoiss et al. [14] observed 10 species of wild bees at Vigna unguiculata in Ghana belonging to the families Apidae (Xylocopa, Apis, and Amegilla), Megachilidae (Megachile eurymera), and Halictidae (Nomia sp.). Kwapong et al. [15] reported that the main insects observed on cowpea flowers were bees such as Apis mellifera, Ceratina sp., Megachile sp., Xylocopa calens, Xylocopa imitator, Braussepis sp., Lipotriches sp., Melecta sp., and Amegilla sp. Kingha et al. [16] reported Apis mellifera as the most abundant insect species visiting $P$. vulgaris flowers in Kenya, followed by Xylocopa calens and X. inconstans. The flowers of long bean attract wild bee pollinators from Apidae, probably because the members of this family have sufficient strength to open the flower to collect pollen and nectar [17]. However, to the best of our knowledge, to date there have been no studies on insect pollinator diversity in green bean cultivation areas 
in Indonesia for comparison purposes. In Sukabumi, West Java, in mustard (Brasica rapus) at an elevation of approximately $854 \mathrm{~m}$ asl, Aouar-Sadli et al. [18] observed insect pollinators from the order Hymenoptera, family Apidae, subfamily Apinae, consisting of the species Apis cerana, Apis dorsata, and Trigona sp., from the subfamily Xylocopinae, the species Xylocopa caerulea, X. confusa, X. latipes, and Ceratina sp., from the family Colletidae, subfamily Hylaeinae Hylaeus $s p$., from the family Halictidae, subfamily Nomiinae Nomia sp., and from the family Scoliidae Compsomeris lindenni. Our study findings indicate that the species composition of insect pollinators on agricultural land is dominated by wild bees.

Elevation strongly influenced the diversity and abundance of wild bee communities. Species richness and abundance increased linearly with increasing elevation, and species diversity was highest at middle elevations. These results are inconsistent with those of Gottlieb et al., [19], who reported that the diversity and abundance of wild bees decreased linearly with increasing elevation from 60 to $2000 \mathrm{~m}$ asl. This difference may be due to differences in the geographical region, climate zone, and range of elevational gradient. A commonly reported pattern in species richness along elevational gradients is a unimodal distribution with a mid-elevation peak [20]. In our study, peak species diversity occurred at middle elevations due to the presence of two species (Apis dorsata and Xylocopa caerulea) that began to appear above $442 \mathrm{~m}$ asl. The presence of the giant honey bee (A. dorsata) at mid-to-high elevations may be due to habitat suitability rather than elevation effects because these bees require a forested habitat with high trees, whereas blue carpenter bees tend to be abundant in cool environments. Large carpenter bees (genus Xylocopa) are wood-nesting generalist pollinators of broad geographical distribution. Their foraging is characterised by a wide range of food plants, long season of activity, tolerance of high temperatures, and activity under low illumination levels [21]. Carpenter bees tolerate high ambient temperatures during foraging, and most species are inactive at low temperatures, and these bees were found in all of our study sites. All of the sites from the lowest to highest elevation had daily temperature ranges appropriate for wild bees. Generally, the genus Xylocopa is able to move around well in a daily temperature range of $25-35^{\circ} \mathrm{C}$ [22]. This heat tolerance suggests efficient heat regulation ability in carpenter bees, possibly controlled by a thermoregulatory centre in the prothorax [23]. In contrast, Apis cerana has a tendency to forage in conditions of warm temperatures [24]. The presence of the three species Megachile relativa, Amegilla cingulata, and Lasioglossum malachurum almost evenly at all elevations studied indicates that these species are able to move around in the range of temperatures that occur at these elevations.

\section{Conclusion}

Eight species of wild bees from four families of the order Hymenoptera were recorded in green bean cultivation areas at seven different elevations in Central Java, Indonesia. Species richness and abundance increased linearly with increasing elevation, and species diversity was highest at middle elevations.

\section{Disclosure}

The English in this document has been checked by at least two professional editors, both native speakers of English. For a certificate, please see: http://www.textcheck.com/certificate/ A8aull.

\section{Competing Interests}

The authors declare that they have no competing interests.

\section{Acknowledgments}

The authors are grateful to Yulia Arnitasari, Tutut Kusuma Wahyuni, Ismayanti Pangalinan, Riadiana Sulistyaningrum, and Ganesha Rifky Rinaldi for assistance with data collection and their encouragement of this study from its inception. This study was a part of a larger research programme funded by Jenderal Soedirman University. They also thank the heads of the Institute of Research and Community Services, Jenderal Soedirman University, for their support.

\section{References}

[1] J. C. Biesmeijer, S. P. M. Roberts, M. Reemer et al., "Parallel declines in pollinators and insect-pollinated plants in Britain and the Netherlands," Science, vol. 313, no. 5785, pp. 351-354, 2006.

[2] M. A. Wall, M. Timmerman-Erskine, and R. S. Boyd, "Conservation impact of climatic variability on pollination of the federally endangered plant, Clematis socialis (Ranunculaceae)," Southeastern Naturalist, vol. 2, no. 1, pp. 11-24, 2003.

[3] V. L. Scaven and N. E. Rafferty, "Physiological effects of climate warming on flowering plants and insect pollinators and potential consequences for their interactions," Current Zoology, vol. 59, no. 3, pp. 418-426, 2013.

[4] W. Karunaratne and J. Edirisinghe, "Diversity of bees at different altitudes in the knuckles forest reserve," Ceylon Journal of Science (Biological Sciences), vol. 37, no. 1, pp. 61-72, 2009.

[5] M. Devoto, D. Medan, and N. H. Montaldo, "Patterns of interaction between plants and pollinators along an environmental gradient," Oikos, vol. 109, no. 3, pp. 461-472, 2005.

[6] I. D. Hodkinson, "Terrestrial insects along elevation gradients: species and community responses to altitude," Biological Reviews, vol. 80, no. 3, pp. 489-513, 2005.

[7] Y. L. Dupont, D. M. Hansen, and J. M. Olesen, "Structure of a plant-flower-visitor network in the high-altitude sub-alpine desert of Tenerife, Canary Islands," Ecography, vol. 26, no. 3, pp. 301-310, 2003.

[8] S. Kimball, "Links between floral morphology and floral visitors along an elevational gradient in a Penstemon hybrid zone," Oikos, vol. 117, no. 7, pp. 1064-1074, 2008.

[9] Ø. Totland, "Environment-dependent pollen limitation and selection on floral traits in an alpine species," Ecology, vol. 82, no. 8, pp. 2233-2244, 2001. 
[10] J. M. Olesen and P. Jordano, "Geographic patterns in plantpollinator mutualistic networks," Ecology, vol. 83, no. 9, pp. 2416-2424, 2002.

[11] B. J. Brosi, G. C. Daily, T. M. Shih, F. Oviedo, and G. Durán, “The effects of forest fragmentation on bee communities in tropical countryside," Journal of Applied Ecology, vol. 45, no. 3, pp. 773$783,2008$.

[12] A. E. Magurran, Ecological Diversity and Its Measurement, Chapman and Hall, London, UK, 1st edition, 1988.

[13] N. McAleece, P. J. D. Lambshead, and G. L. J. Paterson, Biodiversity Pro, The Natural History Museum, London, UK, 1997.

[14] B. Hoiss, J. Krauss, S. G. Potts, S. Roberts, and I. SteffanDewenter, "Altitude acts as an environmental filter on phylogenetic composition, traits and diversity in bee communities," Proceedings of the Royal Society B: Biological Sciences, vol. 279, no. 1746, pp. 4447-4456, 2012.

[15] P. K. Kwapong, P. O. A. Danquah, and A. T. Asare, "Insect floral visitors of cowpea (Vigna unguiculata L.)," Annals of Biological Research, vol. 4, no. 4, pp. 12-18, 2013.

[16] B. M. T. Kingha, F. N. T. Fohouo, A. Ngakou, and D. Brückner, "Foraging and pollination activities of Xylocopa olivacea (Hymenoptera, Apidae) on Phaseolus vulgaris (Fabaceae) flowers at Dang (Ngaoundere-Cameroon)," Journal of Agricultural Extension and Rural Development, vol. 4, no. 6, pp. 330339, 2012.

[17] T. Atmowidi, D. Buchori, S. Manuwoto, B. Suryobroto, and P. Hidayat, "Diversity of pollinator insects in relation to seed set of mustard (Brassica rapus L.: Cruciferae)," HAYATI Journal of Biosciences, vol. 14, no. 4, pp. 155-161, 2007.

[18] M. Aouar-Sadli, K. Louadi, and S. E. Doumandji, "Pollination of the broad bean (Vicia faba L.var. major)(Fabaceae) by wild bees and honey bees (Hymenoptera: Apoidea) and its impact on the seed production in the Tizi-Ouzou area (Algeria)," African Journal of Agricultural Research, vol. 3, no. 4, pp. 266-272, 2008.

[19] D. Gottlieb, T. Keasar, A. Shmida, and U. Motro, "Possible foraging benefits of bimodal daily activity in Proxylocopa olivieri (Lepeletier) (Hymenoptera: Anthophoridae)," Environmental Entomology, vol. 34, no. 2, pp. 417-424, 2005.

[20] S. Volynchik, M. Plotkin, N. Y. Ermakov, D. J. Bergman, and J. S. Ishay, "Presence of a thermoregulatory hot spot in the prothorax of the large carpenter bee and the bumble bee," Microscopy Research and Technique, vol. 69, no. 11, pp. 903-912, 2006.

[21] T. Keasar, "Large carpenter bees as agricultural pollinators," Psyche, vol. 2010, Article ID 927463, 7 pages, 2010.

[22] T. Keasar, A. Sadeh, M. Shilo, and Y. Ziv, "Social organization and pollination efficiency in the carpenter bee Xylocopa pubescens (Hymenoptera: Apidae: Anthophorinae)," Entomologia Generalis, vol. 29, no. 2-4, pp. 225-236, 2007.

[23] K. Tan, S. Yang, Z.-W. Wang, S. E. Radloff, and B. P. Oldroyd, "Differences in foraging and broodnest temperature in the honey bees Apis cerana and A. mellifera," Apidologie, vol. 43, no. 6, pp. 618-623, 2012.

[24] D. Goulson, "Effects of introduced bees on native ecosystems," Annual Review of Ecology, Evolution, and Systematics, vol. 34, no. 1, pp. 1-26, 2003. 

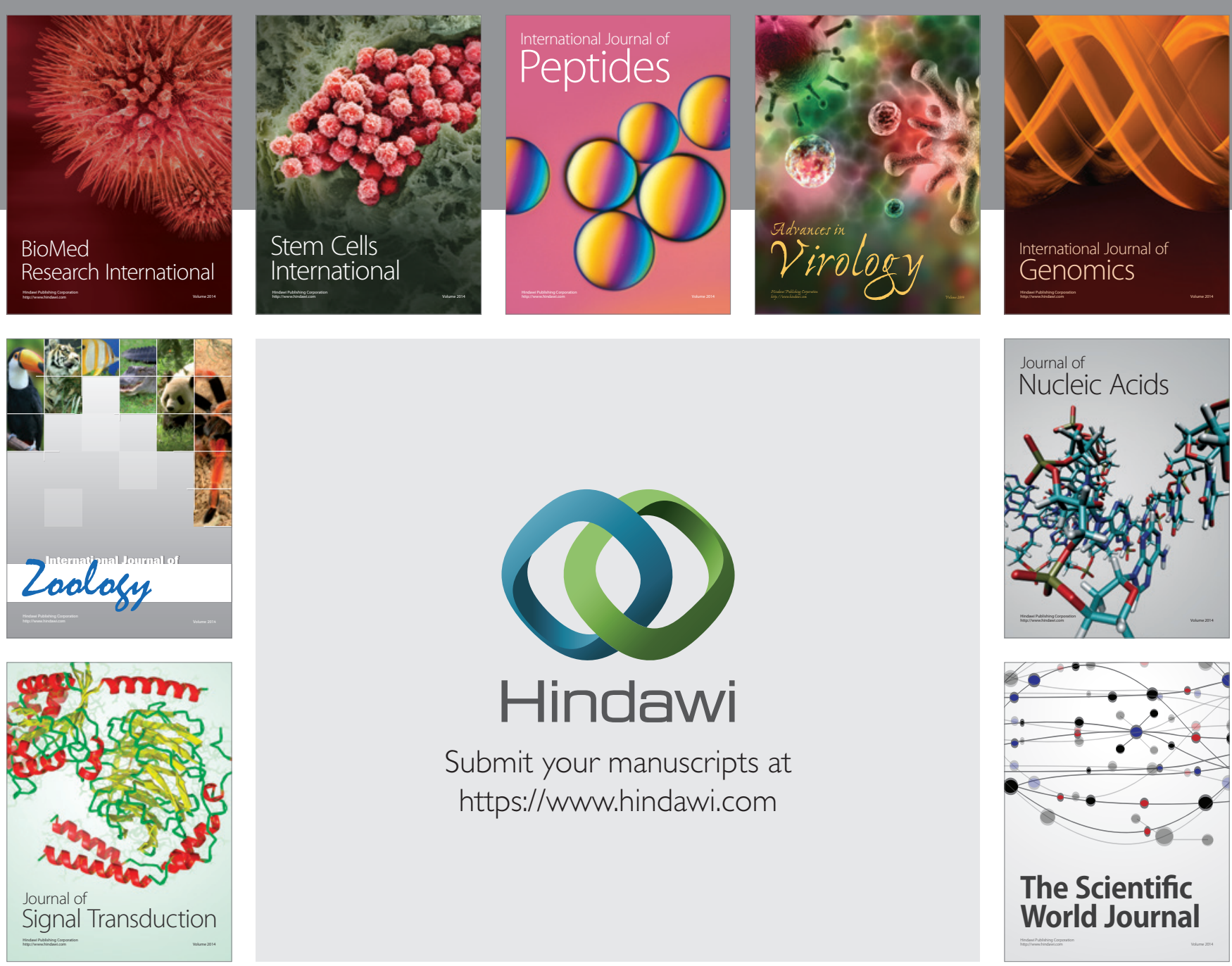

Submit your manuscripts at

https://www.hindawi.com
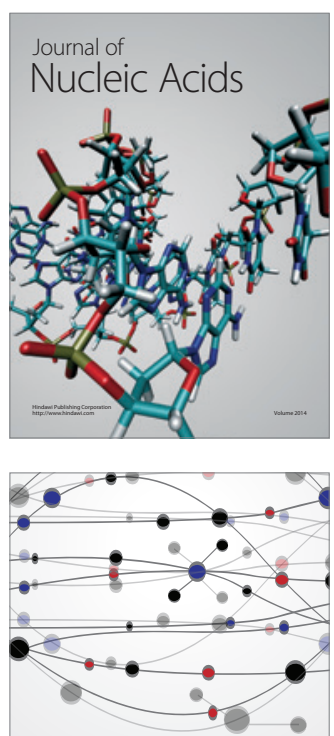

The Scientific World Journal
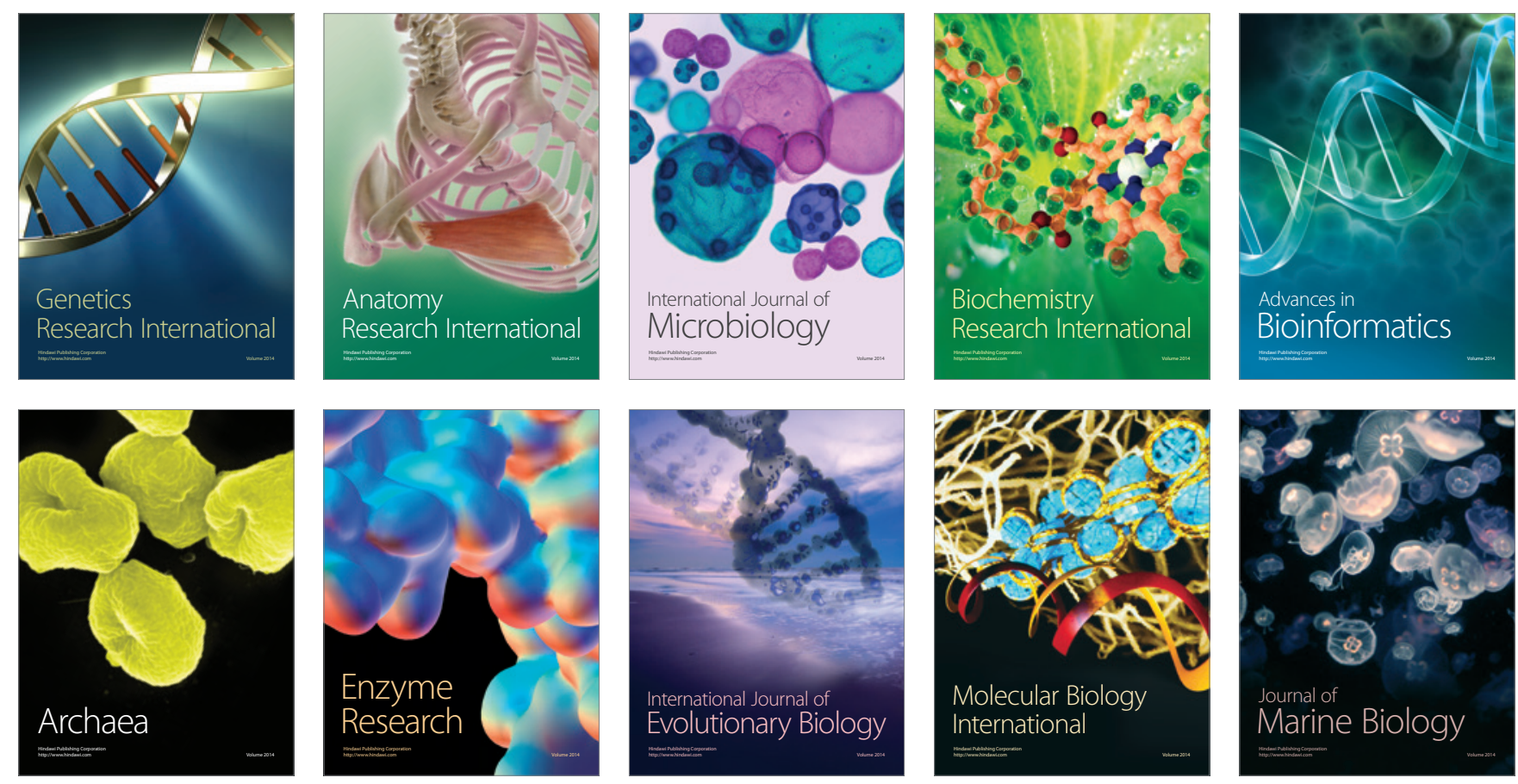